\title{
EARTHQUAKE ANALYSIS OF DIFFERENT CONFIGURATION OF STEEL DOMES USING COMPUTER PROGRAMME
}

\author{
Keyur R. Patel ${ }^{1}$, Anuj K. Chandiwala ${ }^{2}$, Unnati D. Bhagat ${ }^{3}$ \\ ${ }^{1}$ M.Tech Student, Civil Engineering Department, Chhotubhai Gopalbhai Patel Institute of Technology, Bardoli, \\ Gujarat, India \\ ${ }^{2,3}$ Assistant Professor, Civil Engineering Department, Chhotubhai Gopalbhai Patel Institute of Technology, Bardoli, \\ Gujarat, India
}

\begin{abstract}
Domes are one of the oldest magnificent structural systems. They consist of one or more layers of elements that are arched in all directions. Domes are used to cover large areas such as exhibition halls, stadium and concert halls. In this paper one doublelayer steel and two single-layer steel common types of lattice domes have been studied under gravity and earthquake load. The domes have span of 50m, and their height-to-span ratio is 1/2. Here, domes have been analyzed statically under self-weight. Also, for earthquake loads equivalent Seismic Co-efficient and Response Spectrum Analysis (RSA) methods have been employed according to IS 1893:2002. All the three types of steel dome being analyzed by Seismic Co-efficient Method and Response Spectrum Method for Base shear and Modal time periods. Each analysis should be carried out in structural software SAP2000 $v 18$.
\end{abstract}

Keywords: Seismic Co-efficient Method, Response Spectrum Method, SAP2000, Lattice Dome

\section{INTRODUCTION}

Domes are among the oldest forms of three-dimensional structural systems. The earliest record of the existence of a dome was found on an Assyrian bas-relief discovered in the ruins of a palace of Senna-cheribbo in Nineveln around 705 - 681 B.C. (Makowski, 1984) This relief showed a group of buildings covered with both sharply pointed and circular dome structures ${ }^{[3]}$. They consist of one or more layers of elements that are arched in all directions. Domes are used to cover large areas such as exhibition halls, stadium and concert halls. They provide a completely unobstructed inner space and economy in terms of materials. They are lighter compared with the more conventional forms of structures. Structural systems, which enable the designers to cover large spans, have always been popular during the history. Beginning with the worship places in the early times, sports stadia, assembly halls, exhibition centres, swimming pools, shopping centres and industrial buildings have been the typical examples of structures with large unobstructed areas nowadays ${ }^{[2]}$. The earliest domes were mostly all based on a circular floor plan and appeared as roofing systems (Makowski, 1984). The domes of antiquity developed to become religious symbols for pagans, Christians, and Islamic believers ${ }^{[3]}$. Nowadays it is very common to use steel in order to enclose large spans such as $200 \mathrm{~m} \mathrm{length}^{[2]}$.

\subsection{Types of Domes}

There are different types of domes according to pattern of bracings. Below is list of most popular type of domes:
1. Ribbed domes
2. Schwedler domes
3. Lamella domes

4. Two- and three-way (also four-way) grid domes

5. Geodesic domes

\section{METHODOLOGY}

Here two different types of analysis should be carried out for seismic load. Dome is analyzed as per Seismic Coefficient method and response spectrum method.

Seismic co-efficient method is linear static analysis and Response spectrum method is linear dynamic analysis. Both the methods are applied according to IS 1893:2002.

\section{PROBLEM}

Different types of steel domes were modeled and analyzed.

1. Spherical Dome

2. Diamatic Dome

3. Trimmed Schwedler Dome

Different types of domes are analyzed in SAP200. The properties of the dome configurations are considered in the present work are summarized below.

Table 1: Specification Dome

\begin{tabular}{|c|l|}
\hline Material Property & \multicolumn{1}{|c|}{ Dimension } \\
\hline Material & $\begin{array}{l}\text { Steel,E }=2 \times 10^{8} \mathrm{kN} / \mathrm{m}^{3} \\
\mu=0.3, \mathrm{Fy}=250000 \mathrm{kN} / \mathrm{m}^{3}\end{array}$ \\
\hline Frame Section (Pipe Section) & $\begin{array}{l}\text { Outer Diameter }=0.3 \mathrm{~m} \\
\text { Thickness }=0.025 \mathrm{~m}\end{array}$ \\
\hline Diameter of Dome & $50 \mathrm{~m}$ \\
\hline Height of Dome & $25 \mathrm{~m}$ \\
\hline H/S ratio & $1 / 2$ \\
\hline & $\begin{array}{l}\text { 1. Dead Load = Self Weight } \\
\text { of Dome }\end{array}$ \\
Loads Acting on Dome & $\begin{array}{l}\text { Seismic Load as per IS } \\
1893: 2002\end{array}$ \\
\hline
\end{tabular}




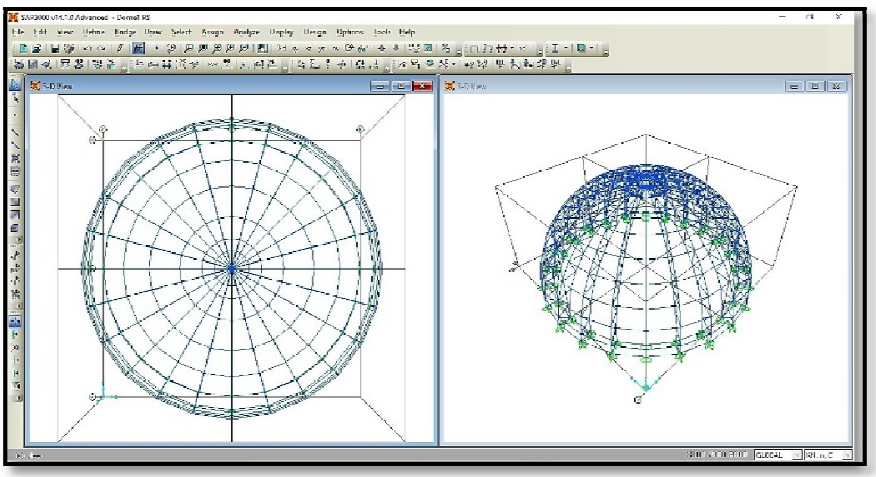

Figure 1: Spherical Dome

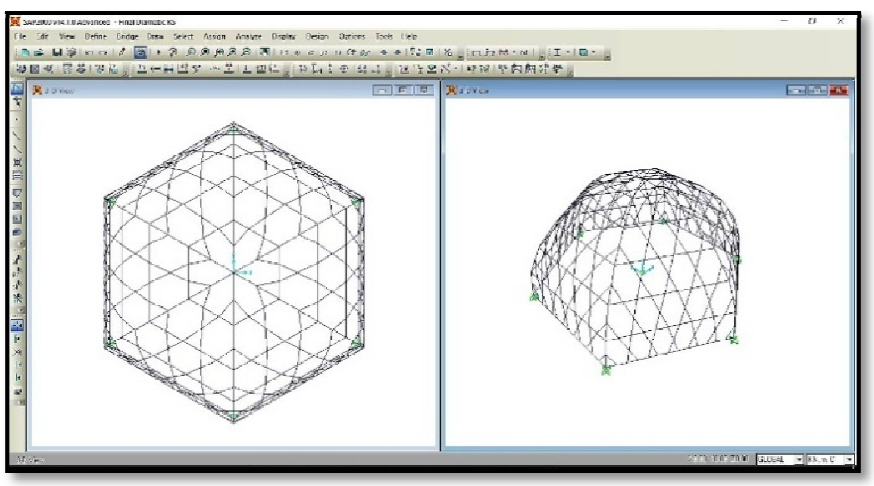

Figure 2: Diamatic Dome

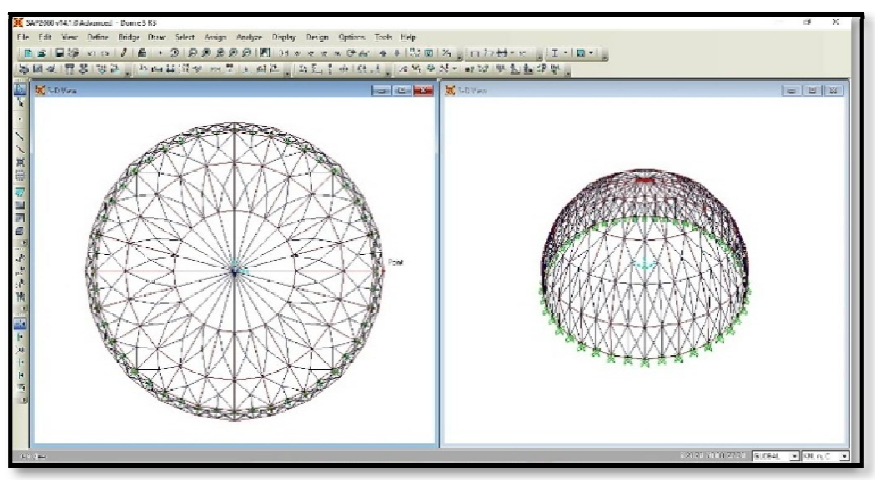

Figure 3: Trimmed Schwedler Dome

\section{RESULTS}

Step by step procedure of modeling of dome and analysis is done in software. After completion of analysis using Seismic co-efficient and Response spectrum method in SAP2000, Results of base shear and time period are compared for each type of dome. All the results and graph developed are given below.

Table -2: Base Shear of Dome

\begin{tabular}{|c|c|c|}
\hline Types of Dome & $\begin{array}{c}\text { Seismic Co- } \\
\text { efficient }\end{array}$ & $\begin{array}{c}\text { Response } \\
\text { Spectrum }\end{array}$ \\
\hline Spherical Dome & 331.2 & 219.402 \\
\hline Diamatic Dome & 154.833 & 66.1 \\
\hline $\begin{array}{c}\text { Trimmed } \\
\text { Schwedler Dome }\end{array}$ & 1080.947 & 827.153 \\
\hline
\end{tabular}

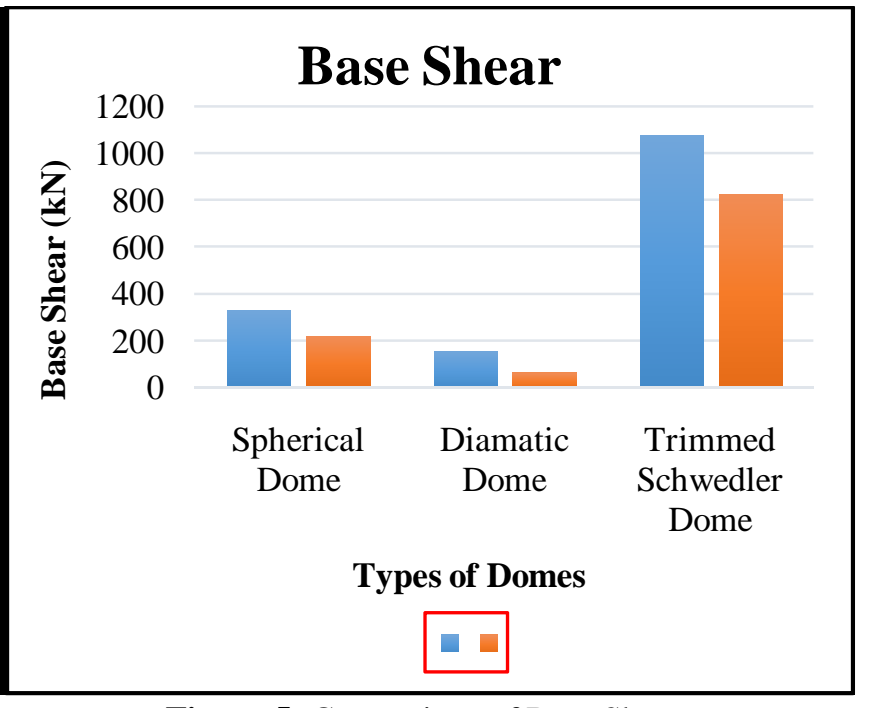

Figure 5: Comparison of Base Shear

Table 3: Modal Time Period of Dome (sec)

\begin{tabular}{|c|c|c|c|}
\hline $\begin{array}{c}\text { Number } \\
\text { of Mode } \\
\text { Shape }\end{array}$ & $\begin{array}{c}\text { Spherical } \\
\text { Dome }\end{array}$ & $\begin{array}{c}\text { Diamatic } \\
\text { Dome }\end{array}$ & $\begin{array}{c}\text { Trimmed } \\
\text { Schwedler } \\
\text { Dome }\end{array}$ \\
\hline 1 & 0.749757 & 0.441851 & 0.188876 \\
\hline 2 & 0.329595 & 0.433538 & 0.188855 \\
\hline 3 & 0.329595 & 0.432047 & 0.14473 \\
\hline 4 & 0.301823 & 0.416708 & 0.131077 \\
\hline 5 & 0.18052 & 0.415371 & 0.130958 \\
\hline 6 & 0.13831 & 0.402801 & 0.130747 \\
\hline 7 & 0.137591 & 0.244931 & 0.126584 \\
\hline 8 & 0.137591 & 0.242355 & 0.126529 \\
\hline 9 & 0.135577 & 0.227343 & 0.125236 \\
\hline 10 & 0.135577 & 0.225247 & 0.121555 \\
\hline 11 & 0.132628 & 0.224058 & 0.121461 \\
\hline 12 & 0.132628 & 0.206082 & 0.120122 \\
\hline
\end{tabular}

\section{Modal Time Period}

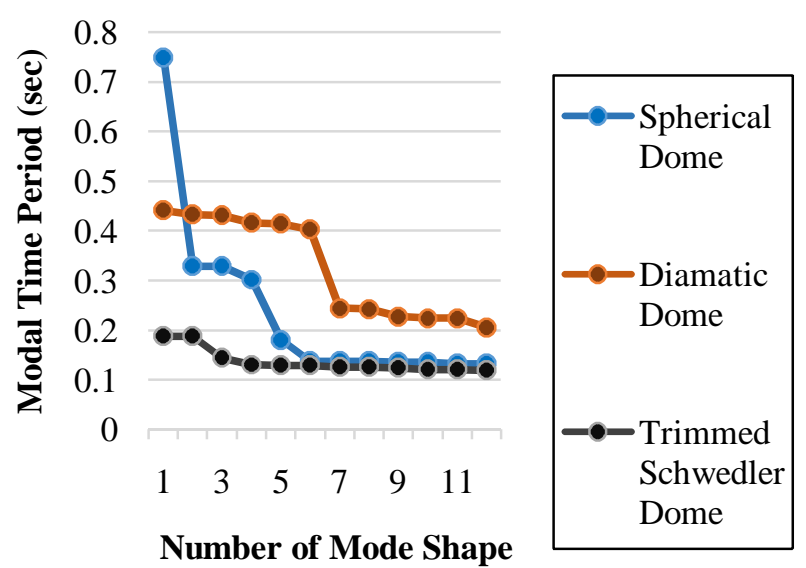

Figure 6: Comparison of Modal Time Period 


\section{CONCLUSIONS}

Analysis was carried out for all three types of domes and results are concluded below:

- Base reaction for Seismic co-efficient method $(1080.947 \mathrm{kN})$ is $30.7 \%$ more than the base reaction for response spectrum method $(827.153 \mathrm{kN})$.

- Base reaction is higher for trimmed Schwedler dome than other types of dome.

- Time period is higher for mode shape number 1 in all types of dome and also as mode shape number increases the value of time period decreases.

- Maximum time period is $0.7498 \mathrm{sec}$ for spherical dome than other types of domes.

\section{REFERENCES}

[1]. Anuj Chandiwala, (2014) "Analysis and design of steel dome", International Journal of Research in Engineering and Technology, Volume: 03, Issue: 03.

[2]. Shah Yash Jayminkumar, Vaibhav Doshi (2016) "A parametric study on steel dome structures", International Journal for Technological Research in Engineering, Volume: 03, Issue: 09.

[3]. Chun Wai Hung, (2009) "A comparative study of structural material for dome construction", Massachusetts Institute of Technology, USA.

[4]. H. S. Jadhav, Ajit S. Patil, (2013) "Parametric study of double layer steel dome with reference to span to height ratio", International Journal of Science and Research, Volume: 02, Issue:08.

[5]. Patricia Murzea, (2013) "Analysis of the behavior of large-span structures in the case of ambient vibrations considering the variety of motion possibilities", Romanian Journal of Acoustics and Vibration, Volume: 10, Issue: 01.

[6]. Xiuli Wang, Jiyun Chen, Chang Wu, (2008) "Dynamic analysis of single layer lattice shell with BRBs", 6th International Conference on Computation of Shell and Spatial Structures, Beijing University of Technology.

\section{BIOGRAPHIES}

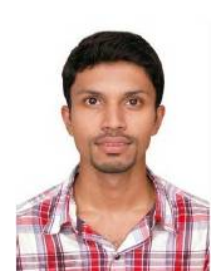

Mr. KEYUR R. PATEL Obtained his Bachelor of Technology (Civil Engineering) from Dharmsinh Desai Institute of Technology and Master in Technology (Structural Engineering) from Chhotubhai Gopalbhai Patel Institute of Technology.

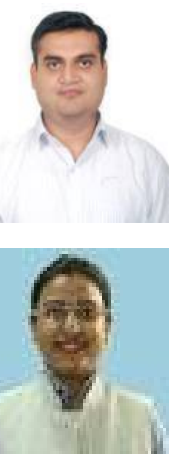

Mr. ANUJ K. CHANDIWALA is working as an Assistant Professor in Chhotubhai Gopalbhai Patel Institute of Technology, in civil Engineering Department.

Ms. UNNATI D. BHAGAT is working as an Assistant Professor in Chhotubhai Gopalbhai Patel Institute of Technology, in civil Engineering Department. 